\title{
Enhancing Environmental Quality of Cities Using Landscape Transformation Projects
}

\author{
Nilgün Güneroğlu*, Makbulenur Bekar \\ Karadeniz Technical University, Faculty of Forestry, Department of Landscape Architecture, Trabzon, Turkey
}

Received: 29 August 2018

Accepted: 15 October 2018

\begin{abstract}
Cities are the most important residential spaces where comfortable living facilities and extensive employment opportunities are provided for inhabitants. Due to these characteristics, preference of urban spaces leads to immigration and urban sprawl. Today, urban transformation projects have become prominent in rehabilitation and restoration of these urban spaces. Urban transformation projects in Turkey were usually conducted in slum areas, historical quarters and quiescent urban spaces for conservation, improvement and development purposes since the 1950s. In the present study, the effects of the urban transformation project implemented in Zağnos Valley in Trabzon Province, Turkey, on landscape quality were determined with a survey study. Study findings demonstrate that the rate of green spaces increased after the transformation project by enhancing environmental quality and recreational opportunities. As a result, it was proved that the study area became more attractive than it was before, based on quantitative user preferences.
\end{abstract}

Keywords: environment, landscape, regeneration, rehabilitation, sustainability

\section{Introduction}

Cities, created by people with a will to conduct collective lives and shaped by social activities, are accepted as the beginning of the history of civilization. They are the result of the stratification of physical, social and cultural elements from different periods in history [1]. Cities that have been differentiated over time throughout history are shaped by the desires and needs of the people and thus gain their identity [2]. Cities that are extremely significant in human history were always preferred settlement spaces based on the possibilities they offer. Thus, the concept of "urbanization" as a reflection of the increasing urban

*e-mail: nayhan@ktu.edu.tr population, introduced related concepts such as "rapid urbanization," "extreme urbanization" and "unplanned urbanization" [3]. Today these concepts are entwined with the concepts of "urbanization" and "urban space," and they are among the most important global topics. Because these concepts affect both the city and the city dwellers, they comprehensively change the relationship between society and the environment [4].

In cities with a dense population, various designs should be conducted to increase the quality of urban spaces and to provide comfort and facilities for users [5]. These designs are conducted in accordance with the urban plan, color, scale and texture, shaping the urban character [6]. The three main objectives of urban design are to engage in solid structural and functional development, while leaving behind traces that would make those who follow the process happy [7]. To 
make the users happy, their needs should be fulfilled, and they should be provided with a more qualified and balanced environment. However, the negative factors such as excessive construction, transportation and green space loss in contemporary cities affect individuals psychologically. These negative factors make it necessary to conduct transformation studies such as restoration, rehabilitation, and reconstruction. In particular, large cities experience the construction of irregular buildings and wrong location choices in construction. According to the DESA-UN [8] data, there is a rapid growth in urban population and 54\% of the global population (about 3.9 billion people) lives in urban areas. This rate is expected to increase by $70 \%$ by 2050 [8]. The rising impact of the increasing population forces people to make a rapid transition from natural vegetation to the built environment. This transition reduces the connection between individuals and nature every day [9]. Urban transformation projects are developed to prevent the negative consequences of the above-mentioned developments, eliminate existing problems, and create healthier, more organized and amenable cities [10-18].

Urban transformation projects are conducted to cope with the changing urban environment, to solve the problem of urban collapse and to meet various socioeconomic goals [11-19]. According to Thomas [20], urban transformation is defined as "a comprehensive vision and action that aims to provide a solution to urban problems and provide a permanent solution for the economic, physical, social and environmental conditions of a region that was exposed to change" [21]. According to Roberts et al. [22], urban transformation is "a comprehensive and integrated set of vision and actions that aim to rehabilitate urban spaces in physical and social collapse through mobilization of dynamics of the local economy to render these areas inhabitable vivid spaces." Urban transformation activities are conducted in large cities worldwide. In fact, these efforts could improve development, inhabitability and vitality in cities [23]. Thomas [20] defined urban transformation as a comprehensive action to provide integrated and sustainable economic and social solutions to several spatial problems [21]. Because, due to changing demands and conditions in time, urban areas that have completed their lifespan wait to be revitalized and the urban spaces that are in physical and social collapse wait to be habitable again.

It was always emphasized that urban projects should focus on people and prioritize the design of more habitable cities [24]. In order to implement the most adequate scenario in these transformation projects, it is necessary to implement the project by following the people [25]. Today, efforts to improve the quality of these spaces gains increasing significance. In particular, visible improvements are observed in the visual quality of the project areas as a result of transformation projects. Visual landscape quality assessment is used to quantify the abovementioned improvements. Visual landscape quality is a product of the interaction of the sensory traits of individuals and the local landscape properties. It is defined as the quality of the visual landscape based on the interpretation and assessment of the individual with respect to the properties of that environment. Furthermore, it is the aesthetic perfection that can be measured by the evaluation of the observers based on the properties of landscapes [26-29]. The visual quality assessment is usually utilized in the said measurements. The visual quality of the areas is usually determined with the user assessments of the photographic presentations of the space based on predetermined parameters $[26,30]$.

The phenomenon of urban transformation was first introduced with renovations conducted in areas of social and economic collapse in Western countries. Urban renewal studies were extensively conducted in the West after the Second World War. However, over time, urban transformations began to be conducted to revitalize, improve and preserve urban spaces. In Turkey, on the other hand, urban transformation has only been initiated since the 2000s. It began with the renewal projects that included the transformation of various urban spaces into spaces for different uses [31]. The first transformation project planned in Trabzon Province was the Zağnos Valley project. The project, conducted as a collaboration of TOKI and the Municipality of Trabzon, aimed to transfer the Zağnos Valley into a green space after the removal of irregular construction. Thus, the present study aimed to observe the spatial changes that occurred in the area as a result of the Zağnos Valley urban transformation project and to determine whether the space has achieved the status of an urban space that fulfills the current needs and expectations of the users after the project. Furthermore, the preference of the valley due to the new character it obtained after the transformation project was examined.

\section{Material and Methods}

\section{Material}

Trabzon is located in the Eastern Black Sea region in Turkey on the Black Sea coast. Trabzon is located in a rugged and mountainous region with several valleys. Zağnos Valley, located in the Trabzon urban center, which has a topography divided by deep valleys, is among the valleys that border the ancient city of Trabzon (Fig. 1).

Zağnos Valley is located to the west of the ancient city of Trabzon, which is a first-degree archeological site that also includes the historical Zağnos Bridge, which provides access to the walled city [21]. Despite being bordered with historical buildings and its natural beauty, new buildings were constructed in Zağnos Valley over time, and it became an unhealthy and unqualified area that contradicted the urban identity (Fig. 2). Thus, the 


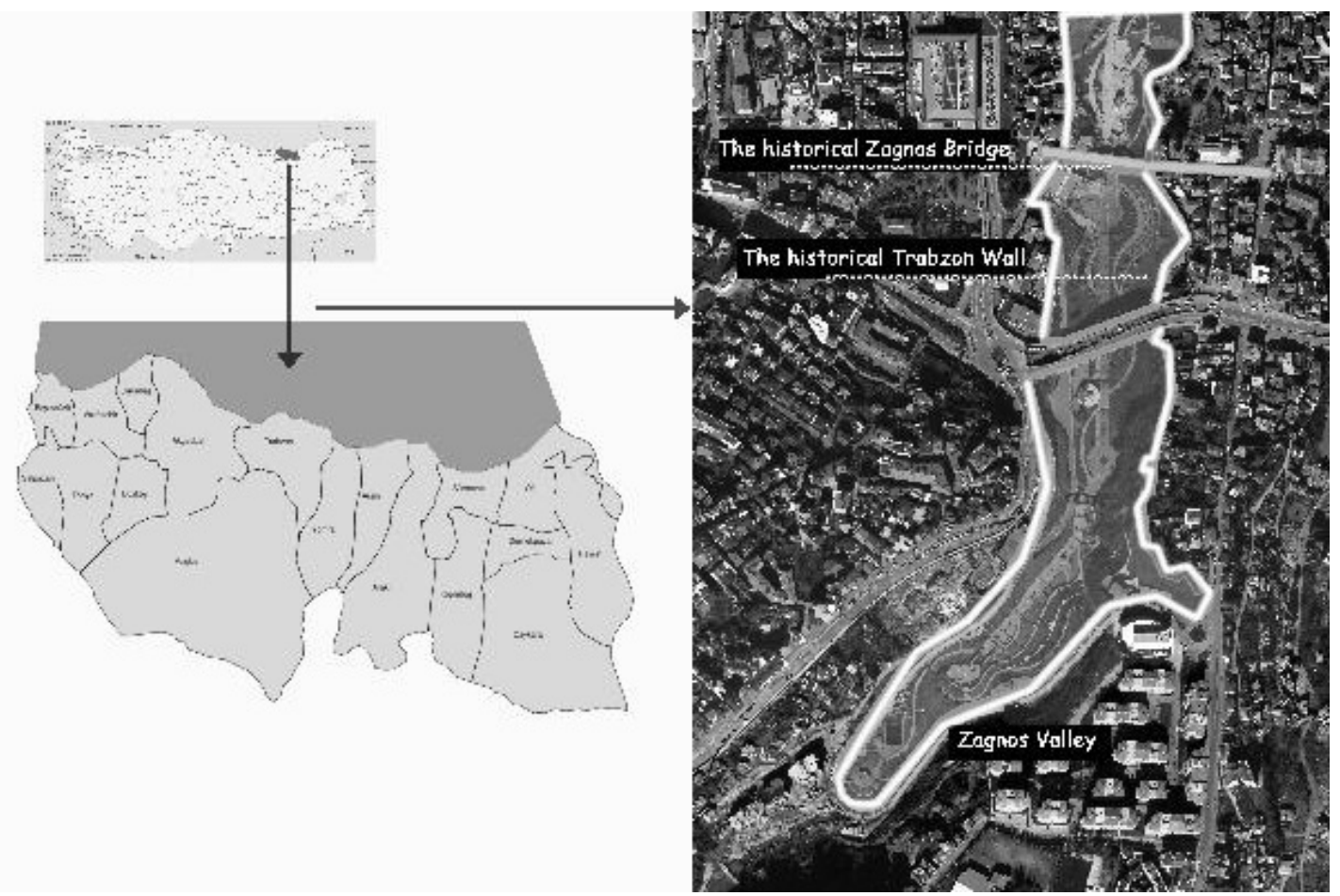

Fig. 1. Study area.

Zağnos Valley Transformation project was needed to create an active green space in the city center, allowing for air circulation and protection of historical values. As a result, the site was selected as an urban transformation area since it was a poor slum area on the limits of a historical site and because of its proximity to the city center.

As a result of the signed protocols, Zağnos Valley was declared an "urban transformation area" with decision No. 284 dated 02.11.2005, and the urban transformation work started. The study material is the Zağnos Valley project area completed within the scope of $900 \mathrm{~m}$ long Zağnos Valley Urban Transformation Project. The first of the three stages of the project covered the area at the south of Gülbahar Hatun Bridge, the second stage included the area between Gülbahar Hatun Bridge and Zağnos Bridge, and the third stage covered the area between Zağnos Bridge and Kahraman Maraş Street (Fig. 3). Restaurants that serve local food and galleries were included in the first stage, stage 2 included a performance area, water and light games, ponds and observation areas, and third stage included mostly children's playgrounds, sports fields and recreational facilities.
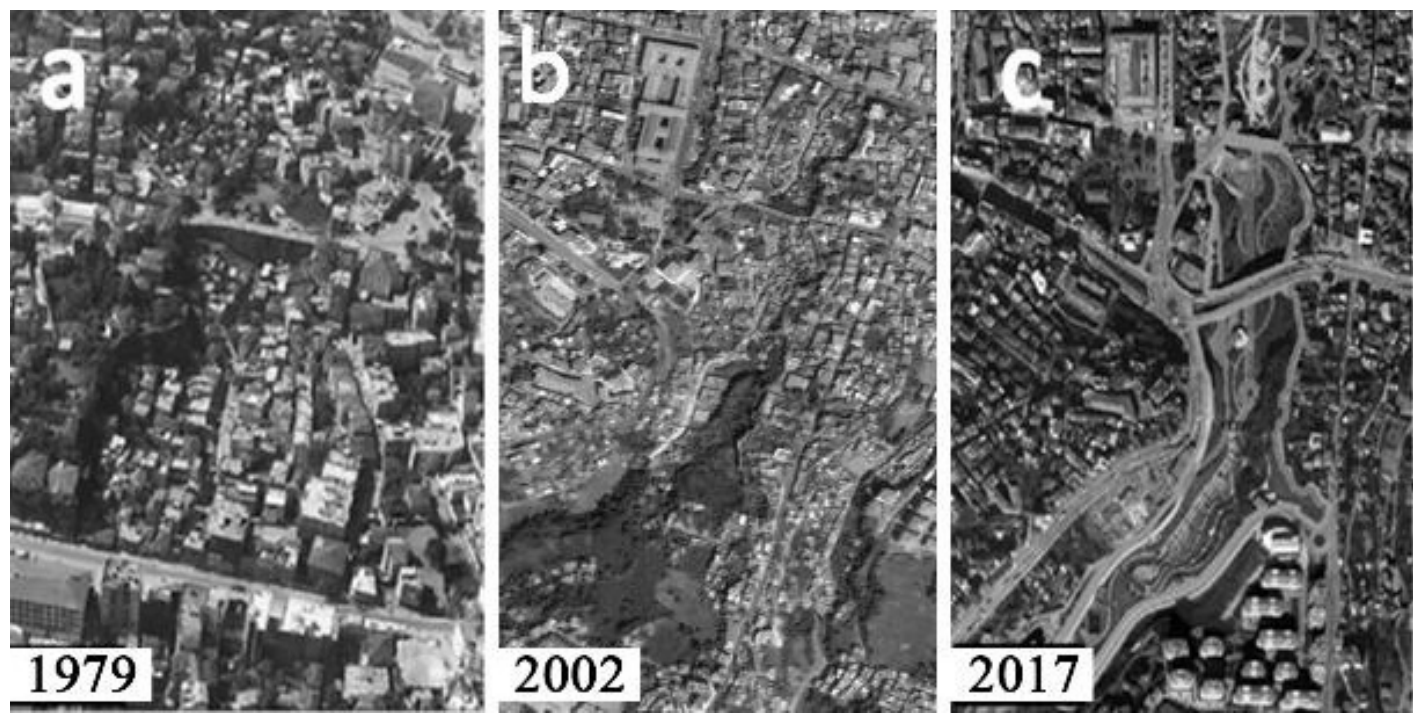

Fig. 2. a) Slums in Zağnos Valley in 1979 [32], b) increasing slums in 2002, and c) 2002 urban transformation project. 


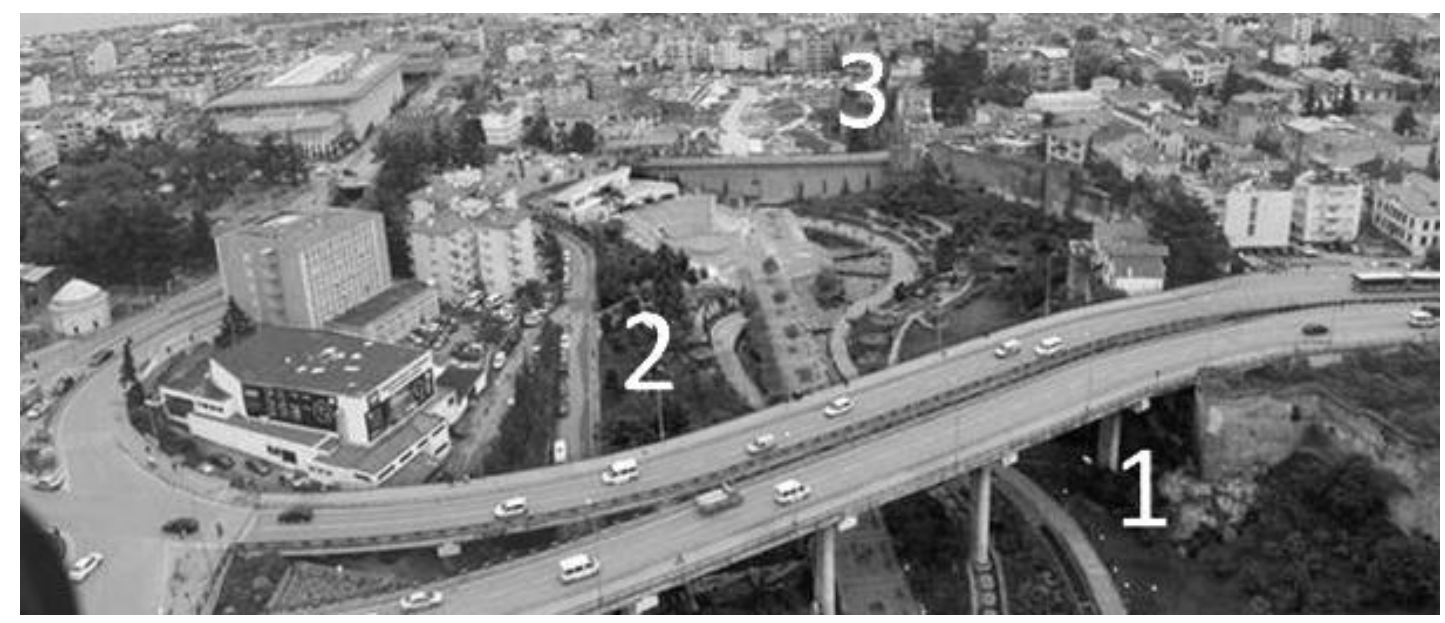

Fig. 3. Zağnos Valley urban transformation areas and stages [33].

\section{Method}

The study included 3 phases. In the first phase, study objectives and the limits of the study area were determined. The second phase included the collection of the data via field study and mapping. The final phase of the study included survey studies that aimed to determine the impact of the transformation project on the landscape quality of the area. The study aimed to demonstrate the spatial development with the transformation project based on the previous and present status of the area and to observe the realization of the objectives of the urban transformation project that was conducted based on current needs. It was aimed
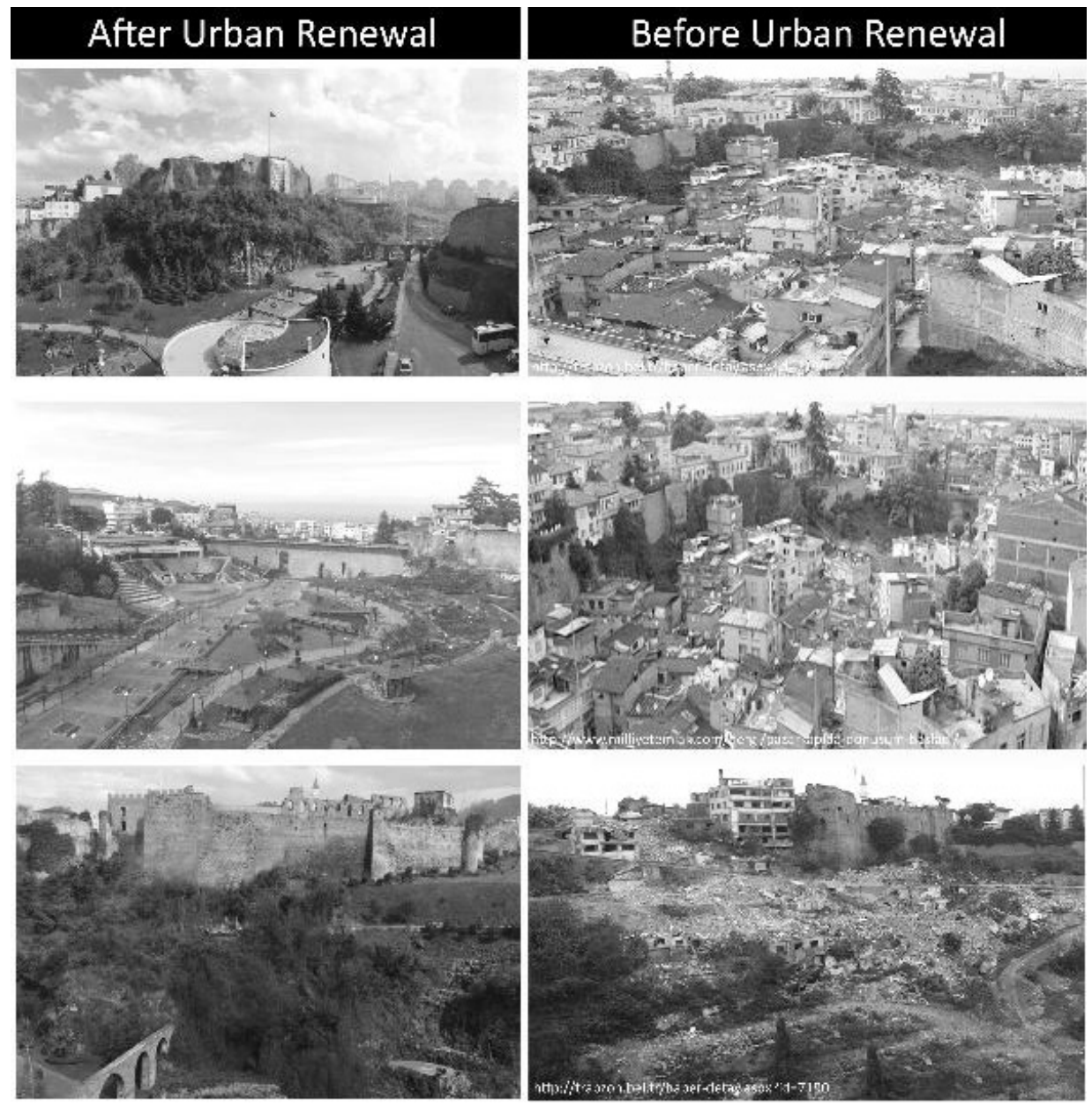

Fig. 4. Zağnos Valley before and after urban transformation. 
to determine the effects of the rehabilitation work on landscape quality based on the old and the new conditions in the valley.

Surveys applied in the study included 3 sections. The first aimed to obtain demographic participant information, the second section identified the preference of the area, and the third aimed to determine the effects of the urban transformation on landscape quality in the site. The parameters used in the third phase of the study were selected from the parameters used in the studies that aimed to determine the landscape quality in the literature and included continuity, unity, perceptibility, legibility, attractiveness, harmony, diversity, complexity, beauty, originality, impressiveness, naturalness, line, color, texture, form, recreation, comfort, relaxation, achievable, memorability, appreciation, protection, development and renewal [28, 34-37]. In order to inquire about each parameter included in the survey, comprehensive questions were designed for each parameter. Thus, 24 parameters were converted into 24 questions and evaluated using the Likert attitude scale. The survey included a 5-point Likert-type scale where participants selected one of the following statements: 'I absolutely agree,' 'I agree,' 'Neither agree nor disagree,' 'I disagree,' and 'I absolutely disagree.' In the survey study, photographs that reflected the old and new conditions in the area were prepared as a result of the literature review and the field study (Fig. 4). Designed survey forms were evaluated by showing the respondents 150 new and old photographs of the valley.
The surveys lasted about 15 minutes and were applied face-to-face with the participants.

The descriptive parameters of landscape quality were achieved statistically with the survey data that was obtained in order to determine the landscape quality of the old and new structure of the valley and examine the differences that occurred after the application of the project in the area. Whether the difference between the landscape quality of the area before and after the project was statistically different and which characteristics were different were identified with analysis of variance by using the one-way ANOVA model. Correlation analysis was conducted to determine the mutual impact of the parameters. Factor analysis is a statistical approach that allows for obtaining new variables by grouping parameters in a study that is conducted with a large number of parameters. In the present study, the most effective factors in determining landscape quality were identified. Statistical analyses were conducted with SPSS 11.5 software in the study. Landscape quality was assessed by measuring the preference of the area with the evaluations of the old and new conditions of the area by the participants based on the determined parameters.

\section{Results and Discussion}

Zağnos Valley, where an urban transformation project was implemented in the city of Trabzon, was

Table 1. Socio-demographic status of participants.

\begin{tabular}{|c|c|c|c|c|c|c|c|}
\hline Variables & & Frequency & $\%$ & Variables & & Frequency & $\%$ \\
\hline \multirow{3}{*}{ Gender } & Male & 46 & 31 & \multirow{3}{*}{ Marital status } & Married & 22 & 15 \\
\hline & Female & 104 & 69 & & Single & 122 & 85 \\
\hline & Total & 150 & 100 & & Total & 150 & 100 \\
\hline \multirow{7}{*}{ Age } & $15-20$ & 23 & 31 & \multirow{7}{*}{ Education } & Uneducated & - & - \\
\hline & $20-25$ & 107 & 56 & & Primary school & 6 & 4 \\
\hline & $25-30$ & 2 & 1 & & Secondary school & 2 & 7 \\
\hline & $30-35$ & 7 & 5 & & High school & - & 30 \\
\hline & $35-40$ & 11 & 7 & & University & 135 & 54 \\
\hline & $40+$ & - & - & & Postgraduate & 8 & 5 \\
\hline & Total & 150 & 100 & & Total & 150 & 100 \\
\hline \multirow{7}{*}{ Occupation } & Unemployed & 2 & 2 & \multirow{7}{*}{ Income status } & No revenue & 112 & 75 \\
\hline & Student & 132 & 88 & & $500-1000$ & 12 & 8 \\
\hline & Officer & 6 & 4 & & $1000-2000$ & 10 & 7 \\
\hline & Worker & - & - & & $2000-3000$ & 0 & - \\
\hline & Housewife & 2 & 1 & & $3000+$ & 16 & 10 \\
\hline & Others & 8 & 5 & & Total & & 100 \\
\hline & Total & 150 & 100 & & & & \\
\hline
\end{tabular}


examined in the study. The previous and current status of the project area were compared and the achievements of the city due to urban transformation and the aim of becoming an urban space that lives up to the expectations were revealed with the conducted survey study. Study findings obtained with the conducted analyzes are presented below.

\section{Participant Profile}

Participant demographics (age, gender, marital status, education level, employment status, income level) are presented in Table 1 as percentages. It can be observed in Table 1 that $31 \%$ of the participants were male and $69 \%$ of the participants were female. Furthermore, $15 \%$ of the participants were married and $85 \%$ were single. Most of the participants $(88 \%)$ declared that they were students.

\section{Area Use}

Study findings demonstrated that the old structure of Zağnos Valley did not offer any utilization possibilities due to the sole presence of residences, and the historical texture in the site could not exert its presence due to illegal construction. It was concluded that as a result of the transformation project, the urban population acquired a green space, the new project provided recreational facilities and the area was able to reflect its historical texture (Fig. 5).

The valley was transformed into a green space with the project and was made available for the use of urban residents. The observations and the survey conducted in the area demonstrated that the area is extremely preferred by urban residents today. Factors such as the accessibility of the area, the availability of modern furniture for sitting-leisure needs and well-maintained state of the area were prominent reasons for the preference of the area. Furthermore, the fact that the new arrangements allowed for the survival of the historical texture in the vicinity of the area was determined to be another important preference factor (Fig. 6).

\section{Landscape Quality}

Correlation analysis was used to determine correlation between the variables. Pearson correlation

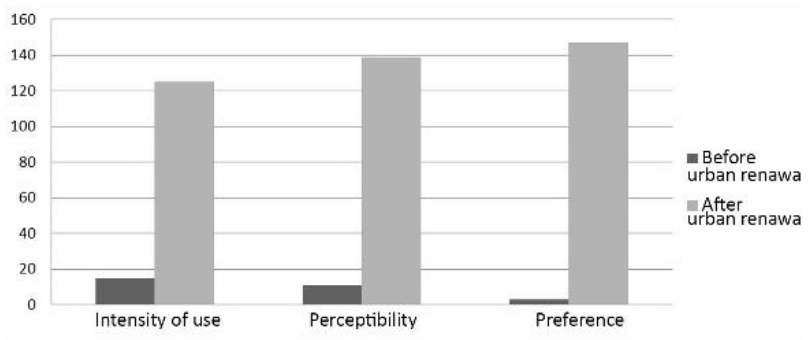

Fig. 5. Use density, perceptibility and preference of Zağnos Valley before and after the project.

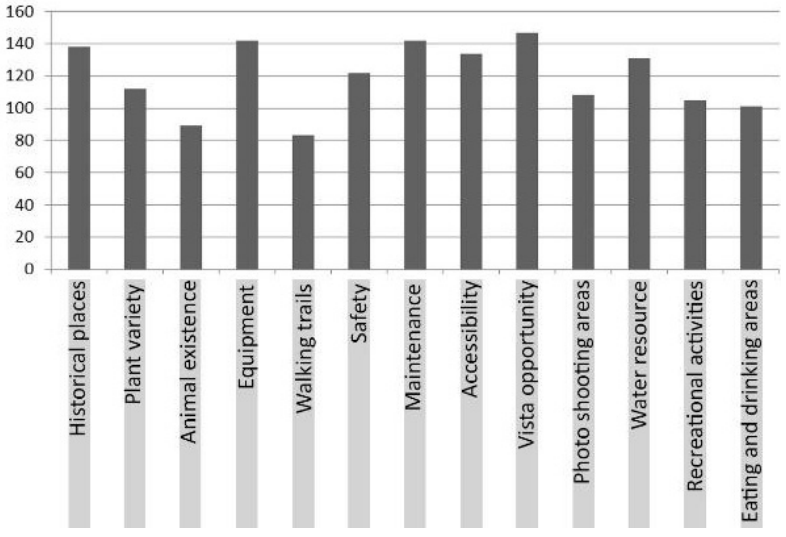

Fig. 6. Factors that affected the preference of Zağnos Valley after the project.

coefficient was calculated at $99 \%$ significance level. Analysis results demonstrated that the highest correlations were observed between legibility and perceptibility $(\mathrm{r}=0.909)$ and between harmonious and continuous $(r=0.904 ; \mathrm{p}<0.01)$. Similarly, there was a high correlation between relaxing-comfortable $(\mathrm{r}=0.898 ; \mathrm{p}<0.01)$ and attractive and beautiful $(\mathrm{r}=0.897 ; \mathrm{p}<0.01)$. Significant values were also determined between impressive and original, unity and harmony and comfortable and recreational $(r \geq 0.8)$.

One-way ANOVA was used to test whether there was a significant difference between 2 different situations determined based on the 24 landscape quality parameters. According to ANOVA results, it was accepted that there was a significant difference between the variables with $\mathrm{F}$ values greater than 1 at $\mathrm{P}<0.05$ significance level. When the parameters that reflected the landscape quality of the old and new states of the study area are examined with the oneway ANOVA test, it was determined that the new state of the area received high scores in "Beautiful" (95\% CI $[3,86-4,16]$ and $\mathrm{P}=0.00)$, "Original" (95\% CI $[3,26-3,58]$ and $\mathrm{P}=0.00)$, "Impressive" (95\% CI [3.99-4.25] and $\mathrm{P}=0.00)$, "Legible" (95\% CI [3.933.25] and $\mathrm{P}=0.00)$, "Attractive" (95\% CI [3,65-3,97] and $\mathrm{P}=0.00)$, "Natural" $(95 \%$ CI [3,17-3,52], and $\mathrm{P}=0.00)$, "Harmonious" $(95 \%$ CI $[3,66-3,97]$ and $\mathrm{P}=0.00)$, "Continuous" ( $95 \% \mathrm{CI}[3,73-4,02]$ and $\mathrm{P}=0.00)$, "Unity" (95\% CI [3,76-4,07] and P = 0.00), "Diversity" $(95 \%$ CI $[3,52-3,83]$ and $\mathrm{P}=0.00)$, "Memorable" $(95 \%$ CI [3.78-4.08] and $\mathrm{P}=0.00)$, "Recreation" (95\% CI $[4,07-4,36]$ and $\mathrm{P}=0.00)$, "Comfortable" $(95 \%$ CI $[3,69$ 3.99] and $\mathrm{P}=0.00)$, "Relaxing" (95\% CI [3,74-4,05] and $\mathrm{P}=0.00)$, "Accessible" $(95 \% \mathrm{CI}[3,50-3,86]$ and $\mathrm{P}=0.00))$, "Protected" $(95 \%$ CI $[3,51-3,84]$ and $\mathrm{P}=0.00)$, "Line" $(95 \% \mathrm{CI}[3,61-3,90]$ and $\mathrm{P}=0.00)$, "Color" (95\% CI [3,75-4,02] and P = 0.00), "Form" (95\% CI $[3,62-3,94]$ and $\mathrm{P}=0.00)$, and "Texture" 53-3, 85] and $\mathrm{P}=0.00$ ) parameters. The old state of the area received high scores in "Complexity" (95\% CI [2,49-2,88] and $\mathrm{P}=0.00)$, "Needs development" (95\% CI $[2,67-3,04]$ and 
Table 2. Landscape quality parameter one-way ANOVA findings.

\begin{tabular}{|c|c|c|c|c|c|c|c|c|}
\hline & & $\mathrm{N}$ & Mean & Std. Deviation & Lower Bound & Upper Bound & $\mathrm{F}$ & Sig. \\
\hline \multirow{3}{*}{ Beautiful } & 1 & 150 & 1,42 & ,678 & 1,31 & 1,53 & 752,720 & 0,000 \\
\hline & 2 & 150 & 4,01 & ,933 & 3,86 & 4,16 & & \\
\hline & Total & 300 & 2,72 & 1,530 & 2,54 & 2,89 & & \\
\hline \multirow{3}{*}{ Original } & 1 & 150 & 1,62 &, 864 & 1,48 & 1,75 & 249,099 & 0,000 \\
\hline & 2 & 150 & 3,40 & 1,084 & 3,23 & 3,58 & & \\
\hline & Total & 300 & 2,51 & 1,326 & 2,36 & 2,66 & & \\
\hline \multirow{3}{*}{ Impressive } & 1 & 150 & 1,47 & ,786 & 1,34 & 1,60 & 380,282 & 0,000 \\
\hline & 2 & 150 & 3,57 & 1,047 & 3,40 & 3,74 & & \\
\hline & Total & 300 & 2,52 & 1,399 & 2,36 & 2,68 & & \\
\hline \multirow{3}{*}{ Perceptible } & 1 & 150 & 1,72 & ,913 & 1,57 & 1,86 & 597,012 & 0,000 \\
\hline & 2 & 150 & 4,12 & ,788 & 3,99 & 4,25 & & \\
\hline & Total & 300 & 2,92 & 1,475 & 2,75 & 3,09 & & \\
\hline \multirow{3}{*}{ Legible } & 1 & 150 & 1,68 & 885 & 1,54 & 1,82 & 590,024 & 0,000 \\
\hline & 2 & 150 & 4,06 & ,808 & 3,93 & 4,19 & & \\
\hline & Total & 300 & 2,87 & 1,462 & 2,71 & 3,04 & & \\
\hline \multirow{3}{*}{ Attractiveness } & 1 & 150 & 1,44 & ,701 & 1,32 & 1,55 & 553,068 & 0,000 \\
\hline & 2 & 150 & 3,81 & 1,012 & 3,65 & 3,97 & & \\
\hline & Total & 300 & 2,63 & 1,471 & 2,46 & 2,79 & & \\
\hline \multirow{3}{*}{ Naturalness } & 1 & 150 & 2,06 & 1,194 & 1,86 & 2,25 & 96,172 & 0,000 \\
\hline & 2 & 150 & 3,35 & 1,087 & 3,17 & 3,52 & & \\
\hline & Total & 300 & 2,70 & 1,311 & 2,55 & 2,85 & & \\
\hline \multirow{3}{*}{ Continuous } & 1 & 150 & 1,51 &, 766 & 1,38 & 1,63 & 609,726 & 0,000 \\
\hline & 2 & 150 & 3,88 & ,889 & 3,73 & 4,02 & & \\
\hline & Total & 300 & 2,69 & 1,446 & 2,53 & 2,86 & & \\
\hline \multirow{3}{*}{ Harmonious } & 1 & 150 & 1,60 &, 858 & 1,46 & 1,74 & 441,607 & 0,000 \\
\hline & 2 & 150 & 3,82 & ,962 & 3,66 & 3,97 & & \\
\hline & Total & 300 & 2,71 & 1,434 & 2,55 & 2,87 & & \\
\hline \multirow{3}{*}{ Unity } & 1 & 150 & 1,60 & ,784 & 1,48 & 1,73 & 527,287 & 0,000 \\
\hline & 2 & 150 & 3,92 & ,952 & 3,76 & 4,07 & & \\
\hline & Total & 300 & 2,76 & 1,449 & 2,59 & 2,92 & & \\
\hline \multirow{3}{*}{ Diversity } & 1 & 150 & 1,82 & ,960 & 1,67 & 1,98 & 286,308 & 0,000 \\
\hline & 2 & 150 & 3,68 & ,936 & 3,52 & 3,83 & & \\
\hline & Total & 300 & 2,75 & 1,326 & 2,60 & 2,90 & & \\
\hline \multirow{3}{*}{ Complexity } & 1 & 150 & 3,41 & 1,484 & 3,17 & 3,66 & 21,344 & 0,000 \\
\hline & 2 & 150 & 2,69 & 1,214 & 2,49 & 2,88 & & \\
\hline & Total & 300 & 3,05 & 1,401 & 2,89 & 3,21 & & \\
\hline \multirow{3}{*}{ Memorable } & 1 & 150 & 2,00 & 1,223 & 1,80 & 2,20 & 236,820 & 0,000 \\
\hline & 2 & 150 & 3,93 & ,924 & 3,78 & 4,08 & & \\
\hline & Total & 300 & 2,97 & 1,450 & 2,80 & 3,13 & & \\
\hline
\end{tabular}


Table 2. Continued.

\begin{tabular}{|c|c|c|c|c|c|c|c|c|}
\hline \multirow{3}{*}{ Recreational } & 1 & 150 & 1,40 &, 723 & 1,28 & 1,51 & 898,838 & 0,000 \\
\hline & 2 & 150 & 4,22 & ,896 & 4,07 & 4,36 & & \\
\hline & Total & 300 & 2,81 & 1,629 & 2,62 & 2,99 & & \\
\hline \multirow{3}{*}{ Comfortable } & 1 & 150 & 1,44 & ,746 & 1,31 & 1,56 & 615,170 & 0,000 \\
\hline & 2 & 150 & 3,84 & ,924 & 3,69 & 3,99 & & \\
\hline & Total & 300 & 2,64 & 1,468 & 2,47 & 2,81 & & \\
\hline \multirow{3}{*}{ Relaxing } & 1 & 150 & 1,43 &, 814 & 1,30 & 1,56 & 590,394 & 0,000 \\
\hline & 2 & 150 & 3,90 & ,939 & 3,74 & 4,05 & & \\
\hline & Total & 300 & 2,66 & 1,515 & 2,49 & 2,83 & & \\
\hline \multirow{3}{*}{ Accessible } & 1 & 150 & 1,88 & 1,067 & 1,70 & 2,05 & 203,710 & 0,000 \\
\hline & 2 & 150 & 3,68 & 1,124 & 3,50 & 3,86 & & \\
\hline & Total & 300 & 2,78 & 1,420 & 2,62 & 2,94 & & \\
\hline \multirow{3}{*}{ Protective } & 1 & 150 & 1,84 & 1,242 & 1,63 & 2,04 & 195,626 & 0,000 \\
\hline & 2 & 150 & 3,68 & 1,025 & 3,51 & 3,84 & & \\
\hline & Total & 300 & 2,76 & 1,463 & 2,59 & 2,92 & & \\
\hline \multirow{3}{*}{$\begin{array}{c}\text { Needs } \\
\text { development }\end{array}$} & 1 & 150 & 4,49 & 1,139 & 4,30 & 4,67 & 149,229 & 0,000 \\
\hline & 2 & 150 & 2,86 & 1,175 & 2,67 & 3,04 & & \\
\hline & Total & 300 & 3,67 & 1,416 & 3,51 & 3,83 & & \\
\hline \multirow{3}{*}{$\begin{array}{l}\text { Needs } \\
\text { renovation }\end{array}$} & 1 & 150 & 4,62 & ,980 & 4,646 & 4,77 & 47,276 & 0,000 \\
\hline & 2 & 150 & 3,80 & 1,066 & 3,63 & 3,97 & & \\
\hline & Total & 300 & 4,21 & 1,100 & 4,08 & 4,33 & & \\
\hline \multirow{3}{*}{ Line } & 1 & 150 & 1,70 & ,825 & 1,56 & 1,83 & 414,421 & 0,000 \\
\hline & 2 & 150 & 3,76 & ,924 & 3,61 & 3,90 & & \\
\hline & Total & 300 & 2,73 & 1,352 & 2,57 & 2,88 & & \\
\hline \multirow{3}{*}{ Color } & 1 & 150 & 1,61 & ,776 & 1,49 & 1,74 & 594,577 & 0,000 \\
\hline & 2 & 150 & 3,88 &, 831 & 3,75 & 4,02 & & \\
\hline & Total & 300 & 2,75 & 1,391 & 2,59 & 2,91 & & \\
\hline \multirow{3}{*}{ Form } & 1 & 150 & 1,88 & 1,042 & 1,71 & 2,04 & 266,384 & 0,000 \\
\hline & 2 & 150 & 3,78 & ,980 & 3,62 & 3,94 & & \\
\hline & Total & 300 & 2,83 & 1,389 & 2,67 & 2,99 & & \\
\hline \multirow{3}{*}{ Texture } & 1 & 150 & 1,76 & 1,115 & 1,58 & 1,94 & 247,705 & 0,000 \\
\hline & 2 & 150 & 3,69 & 1,009 & 3,53 & 3,85 & & \\
\hline & Total & 300 & 2,72 & 1,437 & 2,56 & 2,89 & & \\
\hline
\end{tabular}

$\mathrm{P}=0.00)$ and "Needs renovation" (95\% CI [3,63-3,97] and $\mathrm{P}=0.00$ ) parameters (Table 2).

The next statistical analysis was factor analysis conducted to determine the most active factors that determine landscape quality. The most effective two components in determining landscape quality were found and factor analysis was conducted on these components (Table 3). Analysis results demonstrated that "beautiful, impressive, perceptible, legible, attractive, natural, continuous, harmonious, unity, diversity, memorable, recreational, comfortable, relaxing, accessible, texture, form, color, line, protective" parameters were effective on the first factor that explained $69.7 \%$ of the total variance, while "complex, should be renovated, should be developed" parameters were effective on the second factor, which explained $5.2 \%$ of the total variance.

In the present study that investigated the effects of urban transformation projects on landscape quality, the 
Table 3. Landscape quality factor analysis.

\begin{tabular}{|c|c|c|c|}
\hline \multirow{2}{*}{ Parameters } & \multicolumn{2}{|c|}{ Factor Loads } & \multirow{2}{*}{$\begin{array}{l}\text { Common } \\
\text { Variance }\end{array}$} \\
\hline & 1 & 2 & \\
\hline Beauty & 947 & $-0,42$ & 0,89 \\
\hline Originality & ,878 & 020 & 0,77 \\
\hline Impressiveness & ,902 & 003 & 0,81 \\
\hline Perceptibility & ,905 & ,008 & 0,81 \\
\hline Legibility & 911 & ,001 & 0,81 \\
\hline Attractiveness & 929 & 017 & 0,86 \\
\hline Naturalness & ,726 &, 254 & 0,59 \\
\hline Continuity & ,939 &, 065 & 0,88 \\
\hline Harmony & ,921 &, 010 & 0,84 \\
\hline Unity & ,923 &,- 045 & 0,85 \\
\hline Diversity & ,826 & 071 & 0,68 \\
\hline Memorable &, 810 &, 113 & 0,66 \\
\hline Recreational & ,922 &,- 038 & 0,85 \\
\hline Comfortable & ,928 &,- 068 & 0,86 \\
\hline Relaxing & ,924 &, 030 & 0,85 \\
\hline Achievable & ,760 &, 025 & 0,57 \\
\hline Protection &, 775 &, 100 & 0,61 \\
\hline Line &, 875 & , 105 & 0,77 \\
\hline Color & ,887 &, 045 & 0,78 \\
\hline Form & ,806 &, 014 & 0,65 \\
\hline Texture & ,837 &, 151 & 0,72 \\
\hline Complexity &,- 225 & ,710 & 0,55 \\
\hline Needs development &,- 674 & ,365 & 0,58 \\
\hline Needs renovation &,- 373 & ,687 & 0,61 \\
\hline Variance $(\%)$ & 69,7 & 5,2 & 74,9 \\
\hline
\end{tabular}

valley that was scrutinized within the scope of Zağnos Valley Urban Transformation Project in Trabzon city center was addressed. The significant changes in the perception and use of Zağnos Valley between the old and new status were identified.

Prior to the valley transformation project, it was preferred as a residential area by people, which led to the construction of buildings in the area. Although the area has historical value, the authorities were not able to prevent the construction of unlicensed buildings and urban sprawl occupying the valley, and the valley turned into an unqualified area. Today, transformation projects, along with preservation laws, were introduced as the ecological significance of the valleys for cities and cultural urban values became prominent. Ecological factors such as providing a wind corridor, which has both cultural and urban significance for the city of Trabzon, necessitated the transformation project in Zağnos Valley.
If we need to make certain generalizations for urban transformation projects that exhibit similar geographical, social, time period, application goals, sustainability principles and target characteristics based on the Zağnos Valley example, it can be concluded that urban transformation projects improve the landscape quality of the respective areas, provide recreational facilities and are better preferred by the users. The findings of the present study were consistent with the studies conducted by Sancar and Acar [38], Güneroğlu and Bekar [39], Bülbül [40], and Bogenç [41]. Furthermore, emphasizing the user demands in urban transformation projects can be scrutinized in future studies.

The fact that the survey conducted in the present study demonstrated that the old status of the area scored rather poorly in several parameters used to evaluate landscape quality, and the current new situation performed well in almost all parameters was quite impressive. These findings demonstrated that the possibilities offered by the new situation were pleasing to the users in terms of landscape quality. However, in a study conducted by Gür and Dostoğlu [42], it was determined that the transformed area was not suitable for the local lifestyle, did not create belongingness, and the users were not satisfied with the recreational facilities after the urban transformation project. Thus, it cannot be argued that every urban transformation project would achieve positive results, such as satisfaction of all users or the improvement of the landscape quality of the respective area. It should be considered that every city has different problems and transformation projects should be proposed and implemented based on the particular problems and needs in different cities [43].

Collected data demonstrated that the former state of Zağnos Valley scored well only in the "should be renewed, should be developed and complexity" parameters. In the old unhealthy situation, illegal construction led to the perception of the valley as complex and revealed the necessity of the renewal and development of the valley. It was determined that the current state of the area was perceived as original, impressive, perceptible, legible, attractive, natural, continuous, harmonious, in unity, diverse, memorable, recreational, comfortable, relaxing and accessible, and should be protected and provided more effective views based on design elements such as line, color, form and texture. It was considered that this perception was due to the fact that the area is now free from illegal buildings and the green texture and recreation facilities increased in the area have increased [37]. It was also observed in a study by Hunziker and Kienast [44] that there is a significant correlation between landscape quality and the diversity of the new state with respect to water, vegetation, land structure and space and historical elements.

As a result of the transformation project, the landscape quality of the area was improved due to good maintenance of the area, rich planting elements, beautiful landscapes, the modernity of leisure facilities, 
the presence of historical buildings that remind one of the past, and the presence of water elements. Furthermore, the fact that the area was not zoned for construction after the transformation project and presented as a green space for the urban residents and accessibility of this are located at the city center were determined as the most significant factors for the preference of this area. Bilgili [45] emphasized the significance of accessible green spaces that provide recreational facilities in his study.

Ceylan [46] emphasized the fact that people conduct happier lives in quality environments that include green spaces and that the green spaces improve the quality of life. Thus, it could be stated that individuals felt happy and preferred the area due to the abundance of green spaces in the valley.

\section{Conclusions}

In contemporary cities, transformation projects with different objectives and in different sizes are conducted to meet the new needs that arise from socio-economic and technological developments. Transformation projects that are considered as solutions in urban areas where social, economic and physical problems are experienced for various reasons could help create quality landscapes and provide a sustainable and adequate environment for individuals. Furthermore, such projects can help develop strategies for mitigation and adaptation to climate change [47]. The present study determined the new identity that Zağnos Valley, which was an unhealthy location in the city of Trabzon, acquired with the transformation project and the landscape quality of this new identity. It was determined that the project improved the physical environment and the quality of life in the area. It was also observed that people were informed about the area for sustainability purposes, the area was well maintained and it was used for different activities after the transformation project. In conclusion, it is obvious that the transformation of the Zağnos Valley was a successful work for the city and the urban residents, and could serve as a model for future urban transformation projects.

\section{Conflicts of Interest}

The authors declare no conflict of interest.

\section{References}

1. FERRELL J. Remapping the city: Public identity, cultural space, and social justice. Cultural Criminology: Theories of Crime, 315, 2017

2. SMITH M.P., BENDER T. City and nation: rethinking place and identity. Routledge, 2017.

3. TEKELI İ. Urban, urban rights, urbanization and urban transformation writings. History Foundation Dormitories, 2011.
4. ROMERO-LANKAO P., GNATZ D.M., WILHELMI O., HAYDEN M. Urban sustainability and resilience: from theory to practice. Sustainability, 8 (12), 1224, 2016.

5. WEY W.M., WEI W.L. Urban street environment design for quality of urban life. Social Indicators Research, 126 (1), 161, 2016

6. CARMONA M. Public places, urban spaces: the dimensions of urban design. Routledge, 2010.

7. CUESTA R., SARRIS C., SIGNORETTA P., MOUGHTIN J.C. Urban design: method and techniques. Routledge, 2012.

8. DESA-UN. World Urbanization Prospects: The 2014 Revision, Highlights (ST/ESA/SER.A/352). United Nations, 2014.

9. HADSON C.B., SANDER H.A. Green urban landscapes and school-level academic performance. Landscape and Urban Planning, 160, 16, 2017.

10. JUAN Y.K., ROPER K.O., CASTRO LACOUTURE D., HA KIM J. Optimal decision making on urban renewal projects. Management Decision, 48 (2), 207, 2010.

11. OZTAYSI B., CEVIK ONAR S., KAHRAMAN C. Fuzzy multi criteria prioritization of urban transformation projects for Istanbul. Journal of Intelligent \& Fuzzy Systems, 30 (4), 2459, 2016.

12. WANG H., SHEN Q., TANG B.S., LU C., PENG Y., TANG L. A framework of decision-making factors and supporting information for facilitating sustainable site planning in urban renewal projects. Cities, 40, 44, 2014.

13. WANG A., HU Y., LI L., LIU B. Group decision making model of urban renewal based on sustainable development: public participation perspective. Procedia Engineering, 145, 1509, 2016.

14. PENG Y., LAI Y., LI X., ZHANG X. An alternative model for measuring the sustainability of urban regeneration: the way forward. Journal of Cleaner Production, 109, 76, 2015.

15. LAI Y., PENG Y., LI B., LIN Y. Industrial land development in urban villages in china: a property rights perspective. Habitat International, 41, 185, 2014.

16. MUSAKWA W., VAN NIEKERK A. Implications of land use change for the sustainability of urban areas: a case study of Stellenbosch, South Africa. Cities, 32, 143, 2013.

17. LA ROSA D., PRIVITERA R., BARBAROSSA L., LA GRECA P. Assessing spatial benefits of urban regeneration programs in a highly vulnerable urban context: a case study in Catania, Italy. Landscape and Urban Planning, 157, 180, 2017.

18. ALPOPI C., MANOLE C. Integrated urban regenerationsolution for cities revitalize. Procedia Economics and Finance, 6, 178, 2013.

19. HUSTON S., RAHIMZAD R., PARSA A. 'Smart' sustainable urban regeneration: institutions, quality and financial innovation. Cities, 48, 66, 2015.

20. THOMAS S. A glossary of regeneration and local economic development, local economic strategy center, Manchester, 2003.

21. BÜLBÜL Ş., YILMAZ C. Astudy of the historical development of the Trabzon Zağnos Valley urban regeneration region - a geographic information systems approach. TUJK'2010 Geodesy Symposium in Spatial Planning 24-26 November, Izmir, 2010.

22. ROBERTS P., SYKES H., GRANGER R. (Eds.). Urban Regeneration. Sage, 2016.

23. LI L., HONG G., WANG A., LIU B., LI Z. Evaluating the performance of public involvement for sustainable urban regeneration. Procedia Engineering, 145, 1493, 2016. 
24. ERTAŞ Ș., SADIKLAR Z., KOÇ S., DEMIREL Ö. Sustainable development created by Konya/Sille Hagia Eleni Church in the scope of tourism potential. Journal of Enviromental Protection and Ecology, 18 (3), 1038, 2017.

25. RADULESCU C.M., ŞTEFAN O., RĂDULESCU G.M., RĂDULESCU A.T., RĂDULESCU M.V. Management of stakeholders in urban regeneration projects. case study: Baia-Mare, Transylvania. Sustainability, 8 (3), 238, 2016.

26. WANG R., ZHAO J., LIU Z. Consensus in visual preferences: the effects of aesthetic quality and landscape types. Urban Forestry \& Urban Greening, 20, 210, 2016.

27. KALIVODA O., VOJAR J., SKŘIVANOVÁ Z., ZAHRADNÍK D. Consensus in landscape preference judgments: the effects of landscape visual aesthetic quality and respondents' characteristics. Journal of: Environmental Management, 137, 36, 2014.

28. HUANG J. Landscape visual quality assessment in washtenaw county, school of natural resources and environment university of Michigan, A. Ar. 18 (1), 2014,

29. ÖZGERIŞ M., KARAHAN F. A study on visual quality assessment in recreational facilities\&58; sample of Tortum and Uzundere (Erzurum). Artvin Coruh University Journal of Forestry Faculty, 16 (1), 40, 2015.

30. QI T., ZHANG G., WANG Y., LIU C., LI X. Research on landscape quality of country parks in Beijing as based on visual and audible senses. Urban Forestry \& Urban Greening, 26, 124, 2017.

31. UZUN B., SIMSEK N.C. Upgrading of illegal settlements in turkey; the case of north Ankara entrance urban regeneration project. Habitat International, 49, 157, 2015.

32. SUMERKAN, M.R., photo archive, 2018.

33. URL-1, http://konuttimes.com/gundem/trabzon_kentsel_ donusum_calismalarinda_son_durum $/ 13001$ (arrival at 05.12.2017).

34. EROGLU E., KAYA S., DOGAN T.G., MERAL A., DEMIRCI S., BASARAN N., CORBACI O.L. Determination of the visual preferences of different habitat types. Fresenius Environmental Bulletin, 27 (7), 4889, 2018.

35. TARAKCI EREN E., DÜZENLİ T. Determination of the visual preference levels and perceptual differences in the appearance of certain taxa in different seasons. Fresenius Environmental Bulletin, 26, 8304, 2017.
36. EROĞLU E., MÜDERRISOĞLU H., KESIM G.A. The effect of seasonal change of plants compositions on visual perception. Journal of Environmental Engineering and Landscape Management, 20 (3), 196, 2012.

37. GÜNEROĞLU N. The effect of restoration process on riparian landscapes. Artvin Coruh University Journal of Forestry Faculty. 18 (1), 10, 2017.

38. SANCAR C., ACAR C. Squares as new faces of urban landscape in turkey: transformation project of „Atatürk Square" (Trabzon-Ortahisar City). Inönü University Journal of Art and Design 6 (13), 57, 2016.

39. GÜNEROĞLU N., BEKAR M. Transformation and identity concept: the case of Trabzon city. Kastamonu University Journal of Forestry Faculty, 17 (4), 580, 2017.

40. BÜLBÜL Ş. Urban regeneration in the Zağnos Valley. Karadeniz Technical University, Master thesis, Institute of Science, Trabzon, Turkey, 2008.

41. BOGENÇ Ç. The evaluation of the urban transformation of Zağnos Valley in Trabzon in terms of landscape planning, Bartın University Master's thesis, Natural and Applied Sciences, Bartın, Turkey, 2014.

42. GÜR M., DOSTOĞLU N. Discussing quality of life in urban transformation of Doğanbey, Bursa. Megaron, 11 (1), 89, 2016.

43. FERILLI G., SACCO P.L., TAVANO BLESSI G., FORBICI S. Power to the people: when culture works as a social catalyst in urban regeneration processes (and when it does not). European Planning Studies, 25 (2), 241, 2017.

44. HUNZIKER M.. KIENAST F. Potential impacts of changing agricultural activities on scenic beauty a prototypical technique for automated rapid assessment. Landscape Ecology, 14 (2). 161, 1999.

45. BILGILI B.C. Evaluation of Public green areas adequacy in the city of Çankırı for accessibility. Journal of Tekirdag Agricultural Faculty, 10 (2), 21, 2013.

46. CEYLAN A. Significance of green spaces on making increase of quality of life in urban regeneration projects, Istanbul Technical University, Doctoral dissertation, Institute of Science and Technology, 2007.

47. LAI R., ARCA P., LAGOMARSINO A., CAPPAI C., SEDDAIU G., DEMURTAS C.E., ROGGERO P.P. Manure fertilization increases soil respiration and creates a negative carbon budget in a Mediterranean maize (Zea mays L.)-based cropping system. Catena, 151, 202, 2017. 